\title{
Реканалізація коронарних артерій у пацієнтів із гострим інфарктом міокарда
}

\author{
Аксьонов Є. В., Головенко В. Б., Гуменюк Б. М., Гапоненко А. $Є$. \\ ДУ «Національний інститут серцево-судинної хірургії імені М. М. Амосова НАМН України» (Київ)
}

\begin{abstract}
Робота присвячена вивченню ранніх і відстрочених післяопераційних ангіографічних результатів у хворих із гострим інфарктом міокарда.

В обстеження ввійшло 626 пацієнтів з гострим інфарктом міокарда без елевації сегмента ST, яким на базі рентген-ангіографічного відділення НІССХ імені М. М. Амосова НАМН України проводилися лікувальні інтервенційні процедури з приводу даної патології. Середній вік пацієнтів становив $66,96 \pm 1,81$ року, середня вага $-86,5 \pm 1,44$ кг. Площа ураження міокарда лівого шлуночка при підрахунку QRS-індексу становила у середньому $20,4 \pm 1,2 \%$. У 438 хворих $(69,97 \%)$ при госпіталізації був II ФК серцевої недостатності за T. Killip. У 332 обстежених у ранні терміни гострого інфаркту міокарда було проведено первинну черезшкірну транслюмінальну балонну ангіопластику, а 294 пацієнтам виконано стентування інфаркт-пов'язаної коронарної артерії з одномоментною імплантацією стентів.

У результаті виконаних досліджень було визначено, що первинне стентування виявилося найбільш ефективною методикою реканалізації порівняно з екстреним або відстроченим стентуванням інфарктпов'язаної артерії, що виражалося в більш значущому зменшенні площі первинного гострого інфаркту міокарда порівняно з екстреним стентуванням і відстроченим втручанням.

У групі пацієнтів, у яких проводилося стентування інфаркт-пов'язаної артерії, отриманий кореляційний взаємозв'язок між розвитком залишкового стенозу коронарної артерії більше $30 \%$ і вихідною фракцією викиду лівого шлуночка, вихідним кровотоком по інфаркт-пов'язаній артерії і співвідношенням між діаметром коронарної артерії і діаметром стента, що імплантується.

При статистично однаковій кількості випадків клінічного успіху госпітальна летальність була вищою при стентуванні інфаркт-пов'язаної артерії на 3\% порівняно з черезшкірною транслюмінальною балонною ангіопластикоюу. Однак відстрочені результати тримісячного спостереження показали переваги стентування перед черезшкірною транслюмінальною балонною ангіопластикою - меншу частоту розвитку повторного інфаркту міокарда (на 11,3\%) і менші показники відстроченої тримісячної летальності (на 6,7\%).
\end{abstract}

Ключові слова: реканалізація, гострий інфаркт міокарда, коронарні артерії.

Ішемічна хвороба серця (IXC) натепер є найбільш поширеною патологією в усьому світі [1]. Так, за даними Американської Асоціації Серця (American heart association), $з$ кожних трьох смертей у Сполучених Штатах одна пов'язана із захворюваннями серцево-судинної системи [1].

Показники первинної інвалідності від IXC протягом останніх років стабільно посідають перші місця в структурі причин первинної інвалідності дорослого населення України і фіксуються практично на одному рівні $(20,1 \%$ - у 2009 p.; $19,9 \%$ - у 2010 p.; $20,1 \%$ - y 2011 p.; 19,5\% - y 2012 p.) [2, 3].

Одним 3 ефективних шляхів зменшення відсотка фатальних результатів IXC є ендоваскулярна реканалізація інфаркт-пов'язаної артерії (ІПА) [4]. Дійсно, первинне черезшкірне коронарне втручання з імплантацією стентів нині є стандартною терапією для пацієнтів із гострим інфарктом міокарда (ГІМ) з підйомом сегмента ST (STEMI) [5]. Однак, незважаючи на впровадження нових технологій і методик в інтервенційній терапії ГІМ, використання сучасних стентів і балонів, розроблення ефективних методів фармакологічної підтримки рентген-ендоваскулярної реканалізації і накопичення досвіду фахівців, відсоток перипроцедуральних ускладнень у пацієнтів з ГІМ залишається високим [5].

Останні наукові дослідження зосереджені на скороченні негативних перипроцедуральних клінічних подій, включаючи ішемію, кровотечі і летальність [6]. Однак, згідно з даними Qiao J. і співавт., в сучасних дослідженнях відзначається неузгодженість підходів не тільки до стратегії, а й до тимчасової тактики проведення стентування [4].

Метою даної роботи було вивчення ранніх і відстрочених післяопераційних ангіографічних результатів при проведенні рентген-ендоваскулярної реканалізації коронарних артерій у хворих із гострим інфарктом міокарда.

Матеріали і методи дослідження. У дослідження ввійшло 626 пацієнтів із гострим інфарктом міокарда 
без елевації сегмента ST, яким на базі рентген-ангіографічного відділення НІССХ імені М. М. Амосова НАМН України проводились діагностичні та лікувальні інтервенційні процедури з приводу даної патології.

Вік пацієнтів коливався від 62 до 73 років (у середньому 66,96 $\pm 1,81$ року). Середня вага становила $86,5 \pm 1,44$ кг (від 67 кг до 102 кг).

Усі пацієнти були обстежені згідно з протоколом, прийнятим у НІССХ імені М. М. Амосова НАМН України для даної категорії хворих.

Діагноз ГІМ виставлявся на підставі клінічних даних (більше 30 хв не купірується інтенсивний ангінозний напад); даних ЕКГ (депресія сегмента ST мінімум на 2 мм від ізолінії, інверсія зубця Т); показниках клінічного аналізу крові: лейкоцитоз, підвищення рівня ферментів у сироватці крові (тропонін І, МБ - КФК, АСТ, ЛДГ)); даних ультразвукового дослідження серця (виявлення зон акінезіі).

Середній час надходження хворих до відділення від

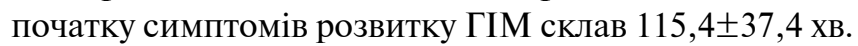

Площа ураження міокарда лівого шлуночка (ЛШ) при підрахунку QRS-індексу становила у середньому $20,4 \pm 1,2 \%$. У 438 хворих $(69,97 \%)$ при надходженні був II ФК серцевої недостатності за Т. Killip.

Радіальний доступ застосовувався у 94,1\% випадків, феморальний - у 5,9\% пацієнтів. Гемодинамічно значущою вважалася оклюзія просвіту артерії більше $50 \%$.

332 обстеженим у ранні терміни інфаркту міокарда (IM) була проведена первинна балонна ангіопластика IПА, а 294 пацієнтам було виконано стентування IПА з одномоментною імплантацією стентів у різні коронарні артерії. Загальна кількість імплантованих стентів склала 415 (у середньому 1,4士0,3 на одного пацієнта).

Процедура рентген-ендоваскулярного стентування виконувалася відповідно до стандартних методик. Рутинна терапія, що проводилася під час ангіопластики, вмішувала нітрати, клопідогрель і гепарин. Технічні аспекти процедури, що включали вибір стента і балона, тривалість інфляції і тиску, визначалися кожним оператором індивідуально. У 26,9\% випадків, у зв'язку з виявленням тромбозів коронарних артерій, рентгенендоваскулярні втручання поєднувалися 3 аспіраційною тромбоекстракцією.

Статистична обробка отриманих результатів була проведена з використанням програм «Excel 2007» для Microsoft Office i Statistica 6.0, з використанням статистичних методів, що включали параметричні і непараметричні тести, регресійний аналіз. Статистично достовірними вважалися отримані результати при $\mathrm{p}<0,05$.

Результати та обговорення. Первинному стентуванню піддалися 70,4\% пацієнтів, екстреному стентуванню - 18,7\% прооперованих, а відстроченому стентуванню - 10,9\% обстежених (табл. 1). Черговість виконання стентування визначалася часом надходження пацієнтів у хірургічне відділення. При цьому при загальній

\section{Таблиця 1}

Результати первинного, екстреного і відстроченого стентування у пацієнтів із ГІМ

\begin{tabular}{lcccc} 
& \multicolumn{2}{c}{$\begin{array}{c}\text { Кількість } \\
\text { пацієнтів }\end{array}$} & \multicolumn{2}{c}{$\begin{array}{c}\text { Летальний } \\
\text { результат }\end{array}$} \\
\cline { 2 - 5 } Вид стентування & $\mathbf{n}$ & $\mathbf{\%}$ & $\mathbf{n}$ & $\%$ \\
\hline Первинне стентування & 207 & 70,4 & 3 & $1,4^{1 *} / 1,02^{2}$ \\
\hline Екстрене стентування & 55 & 18,7 & 8 & $14,5^{1} / 2,7^{2}$ \\
\hline $\begin{array}{l}\text { Відстрочене стенту- } \\
\text { вання }\end{array}$ & 32 & 10,9 & 4 & $12,5^{1} / 1,4^{2}$ \\
\hline Усього & 294 & 100 & 15 & $/ 5,1^{2}$
\end{tabular}

Примітка: ${ }^{1}$ - відсоток відносно кількості пацієнтів у своїй групі; 2 - відсоток відносно загальної кількості пацієнтів, що піддалися стентуванню; * - p $<0,01$ відносно показників паралельної групи

летальності 5,1\% кількість фатальних результатів при первинному стентуванні було на $13,1 \%$ менше порівняно з екстреним стентуванням і на $11,1 \%$ - порівняно з відстроченим стентуванням ( $<0,01)$ (табл. 1).

Порівняльна характеристика результатів первинного, екстреного і відстроченого стентування наведена в табл. 1.

Найбільший відсоток летальних випадків відзначено у пацієнтів, які мали клінічно підтверджену ішемію міокарда протягом більше 90 хв і яким потім було виконано екстрене стентування ІПА (табл. 1). Значний відсоток фатальних наслідків реєструвався і у групі пацієнтів із відстроченим стентуванням коронарних артерій (KA), який, проте, був на $2 \%$ меншим порівняно з групою екстреного стентування (p>0,1) (табл. 1).

Незважаючи на проведену ендоваскулярну коронарну реваскуляризацію, вихідний ГІМ, який був діагностований початково при госпіталізації пацієнтів у клініку, мав форму великовогнищевого IM у 0,97\% випадків (2 пацієнти) після первинного стентування, після екстреного стентування подібна картина спостерігалася у 7 пацієнтів (12,7\% випадків), і після відстроченого стентування така форма IM реєструвалася у 4 хворих (12,5\% випадків) (рис. 1).

Після проведеної ангіопластики вихідний IM зменшувався до дрібновогнищевого у 61 пацієнта (29,5\% випадків) після первинного втручання, що було на 23,2\% менше порівняно з групою пацієнтів, у яких проводилося екстрене стентування (52,7\% випадків (29 пацієнтів)) ( $\mathrm{p}=0,00247)$. Порівняно з пацієнтами, у яких проводилися відстрочені втручання, даний показник був менше на 36,1\% (p=0,00139) (рис. 1). Різниця між групами екстреного та відстроченого стентування в показниках реєстрації дрібновогнищевого ІМ становила $12,9 \%$ на користь групи екстреного стентування $(\mathrm{p}=0,00145)$ (рис. 1).

Цікаво відзначити, що відсутність ЕКГ-ознак інфаркту міокарда в основному спостерігалася у 69,5\% 


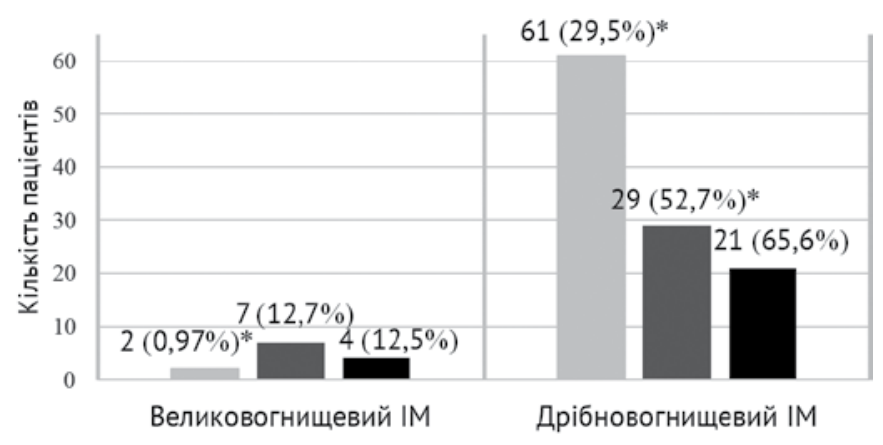

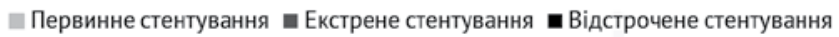

\section{Рис. 1. Перебіг вихідного ГІМ після ендоваскулярного втручання в обстежених групах}

(Примітка: * $-\mathrm{p}<0,05$ )

пацієнтів після первинної процедури стентування, у $34,4 \%$ випадків - після екстреної процедури і у $29,1 \%$ після відстроченої процедури (рис. 1).

У групі пацієнтів, у яких було проведено екстрене стентування, в 5,5\% випадків (3 пацієнти) відзначали гострий тромбоз стента в перші 4-12 годин після рентген-ендоваскулярного втручання і в $1,8 \%$ випадків (1 пацієнт) - на 2-гу добу захворювання. У 2 пацієнтів (3,6\% випадків) із тромбозом стента проведена механічна реканалізація і повторна черезшкірна транслюмінальна балонна ангіопластика (ЧТБА) оклюзії (в 1 пацієнта $з$ повторним IM була проведена механічна реканалізація підгострого тромбозу стента, яка виявилася невдалою), а в 1 випадку з летальним результатом повторну ЧТБА провести не вдалося.

У групі пацієнтів, у яких було виконано відстрочене стентування, в 6,2\% випадків (2 пацієнти) в перші години після ендоваскулярної реканалізації КА спостерігався гострий тромбоз стента, що потребувало проведення повторних ЧТБА, з позитивним ефектом. Ще у 2 пацієнтів розвинувся підгострий тромбоз стента, що в 1 випадку стало причиною летального результату, а в іншому - спричинило розвиток рецидиву IM.

Таким чином, проводячи порівняльну характеристику ускладнень, що виникали при стентуванні, які проводилися в різний час після розвитку IM (екстрене стентування, первинне стентування, відстрочене стентування), можна зробити висновок, що найбільш ефективною методикою відновлення кровотоку в ішемізованій зоні міокарда було первинне стентування.

У ході роботи нами був проведений перехресний кореляційний аналіз для виявлення можливих факторів ризику розвитку залишкового стенозу при проведенні процедури стентування ІПА у пацієнтів з ГІМ. В результаті аналізу було визначено, що в групі пацієнтів, у яких проводилося стентування ІПА, був отриманий помірний позитивний кореляційний взаємозв'язок між розвитком залишкового стенозу КА більше $30 \%$ і такими показниками, як вихідна ФВ лівого шлуночка $(\mathrm{r}=0,425 ; \mathrm{p}=0,0025)$, вихідний кровотік по ІПА $(\mathrm{r}=0,418 ; \mathrm{p}=0,0047)$, і співвідношенням між діаметром коронарної артерії і діаметром стента, що імплантується $(\mathrm{r}=0,523 ; \mathrm{p}=0,0031)$.

Ангіографічне дослідження бічних гілок при біфуркаційному ураженні ІПА виявило, шо при проведенні первинного та відстроченого стентування біфуркаційне ураження ІПА визначалося в $28,6 \%$ випадків (84 пацієнти) і у 32,3\% випадків (95 пацієнтів) відповідно. Однак у результаті стентування лише у 40 (13,6\% випадків) і 32 (10,9\% випадків) пацієнтів спостерігали оклюзію бічної гілки (p>0,05). При ЧТБА оклюзію бічної гілки після проведення процедури спостерігали в 17,8\% випадків (59 пацієнтів).

Таким чином, при проведенні рентген-ендоваскулярної коронарної ангіопластики (як при ЧТБА, так і при стентуванні) в більшості випадків не відзначалося оклюзії бічних гілок, що відходять від місця виконання процедури. У той же час при стентуванні ІПА в меншому відсотку випадків, ніж при ЧТБА, спостерігалося оклюзуюче ураження бічних гілок.

Слід зазначити, що оклюзія бічних гілок, яка спостерігалася після виконання рентген-ендоваскулярних процедур у переважній більшості випадків, не супроводжувалася негативною ЕКГ-динамікою з розширенням зони ураження або негативною клінічною динамікою. Даний факт можна пояснити тим, що в цих гілках від самого початку був відсутній ефективний кровотік, оскільки вони перебували дистальніше оклюзуючого ураження ІПА, а відновлення їх функціональної активності відбувалося тільки після реканалізації ІПА.

У значної кількості пацієнтів проведення ендоваскулярних процедур визначало стабілізацію клінічного стану і відсутність нападів стенокардії. Однак при про-

\section{Таблиця 2}

Клінічні результати, зареєстровані у пацієнтів із ГІМ після рентген-ендоваскулярних процедур

\begin{tabular}{lcc} 
Показники & $\begin{array}{c}\text { Стентування } \\
\text { (n=294) }\end{array}$ & $\begin{array}{c}\text { ЧТБА } \\
\text { (n=332) }\end{array}$ \\
\hline Відсутність стенокардії & $122(41,5 \%)^{*}$ & $113(34 \%)$ \\
\hline Тромбоз/реоклюзія (ТІМІ 0-1) & $8(2,7 \%)$ & $17(5,1 \%)$ \\
\hline $\begin{array}{l}\text { Повторні втручання } \\
\text { (ЧТБА, стентування, АКШ) }\end{array}$ & $26(8,8 \%)^{*}$ & $14(4,2 \%)$ \\
\hline Клінічний успіх & $255(86,7 \%)$ & $\begin{array}{c}271 \\
(81,6 \%)\end{array}$ \\
\hline Госпітальна летальність (10 діб) & $15(5,1 \%)^{*}$ & $7(2,1 \%)$ \\
\hline Повторний ІМ у басейні ІПА & $16(5,4 \%)^{*}$ & $55(16,7 \%)$ \\
\hline Відстрочена летальність (3 міс.) & $12(4,1 \%)^{*}$ & $36(10,8 \%)$
\end{tabular}

Примітка: * $-\mathrm{p}<0,05$ 

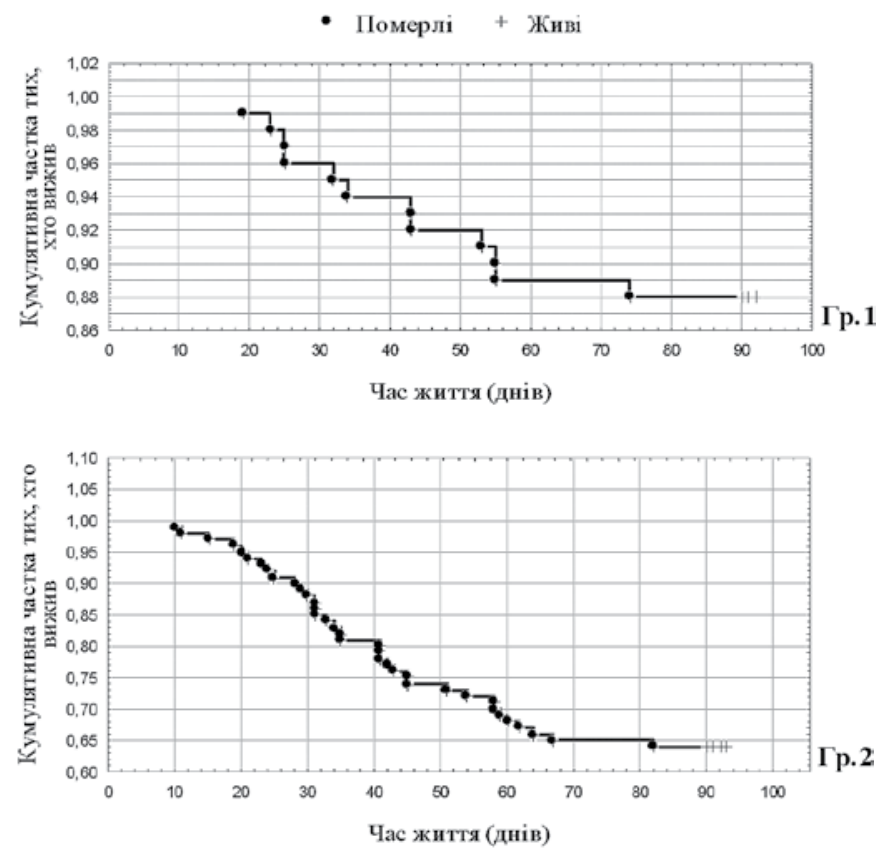

Рис. 2. Криві кумулятивного виживання у відстроченому періоді в обстежених пацієнтів

(Примітка: Гр. 1 - Крива кумулятивного виживання у відстроченому періоді у пацієнтів із ГІМ, яким було виконано стентування КА; Гр. 2 - Крива кумулятивного виживання у відстроченому періоді у пацієнтів із ГІМ, яким було виконано ЧТБА)

веденні порівняльного аналізу між групою хворих, які пройшли процедуру стентування, і пацієнтів, яким була проведена балонна ангіопластика, відзначено, що в групі простентованих пацієнтів відсутність стенокардії реєструвалася на 7,5\% частіше, ніж у групі пацієнтів, яким було проведено ЧТБА ( $\mathrm{p}=0,04328)$ (табл. 2).

Ускладнення у вигляді тромбозу/реоклюзії ІПА відзначалися на 2,4\% менше при імплантації стентів ( $\mathrm{p}=0,1729)$, а кількість повторних втручань була вдвічі меншою у пацієнтів, яким проводилася балонна ангіопластика $(\mathrm{p}=0,0041)$ (табл. 2).

При статистично однаковій кількості випадків клінічного успіху $(\mathrm{p}=0,6751)$ госпітальна летальність була вищою при стентуванні КА на $3 \%(\mathrm{p}=0,0137)$ (табл. 2). Однак відстрочені результати тримісячного спостереження показали переваги імплантації стентів у плані меншої частоти розвитку повторного IM у басейні ІПА, який спостерігався на 11,3\% частіше у пацієнтів із балонною ангіопластикою ( $\mathrm{p}=0,01328)$. До того ж показники відстроченої тримісячної летальності були на $6,7 \%$ меншими у групі стентування порівняно з групою ЧТБА ( $\mathrm{p}=0,01159)$ (табл. 2, рис. 2).

\section{Висновки}

1. Первинне стентування виявилося найбільш ефективною методикою реканалізації порівняно з екстреним або відстроченим стентуванням інфарктпов'язаної артерії, що виражалося в більш значущому зменшенні площі первинного ГІМ порівняно з екстреним стентуванням і відстроченим втручанням.

2. У групі пацієнтів, у яких проводилося стентування інфаркт-пов'язаної артерії, отриманий кореляційний взаємозв'язок між розвитком залишкового стенозу коронарної артерії більше $30 \%$ і вихідною фракцією викиду лівого шлуночка, вихідним кровотоком по інфаркт-пов'язаній артерії і співвідношенням між діаметром коронарної артерії та діаметром стента, що імплантується.

3. При статистично однаковій кількості випадків клінічного успіху госпітальна летальність була вищою при стентуванні інфаркт-пов'язаної артерії на $3 \%$ порівняно із черезшкірною транслюмінальною балонною ангіопластикою. Однак відстрочені результати тримісячного спостереження показали переваги стентування перед черезшкірною транслюмінальною балонною ангіопластикою у плані меншої частоти розвитку повторного інфаркту міокарда (на $11,3 \%$ ) і менших показників відстроченої тримісячної летальності (на 6,7\%).

\section{Література}

1. Go AS, Mozaffarian D, Roger VL [et al.]. Executive summary: heart disease and stroke statistics - 2013 update: a report from the American Heart Association. Circulation. 2013;127(1):143-52.

2. Гандзюк ВА. Аналіз захворюваності на ішемічну хворобу серця в Україні. Український кардіологічний журнал. 2015;3:45-52.

3. Коваленко ВМ, Корнацький ВМ. Регіональні медико-соціальні проблеми хвороб системи кровообігу. Динаміка та аналіз. К.: МОЗ України, ДУ «УІСД МОЗ України», 2013. 239 с.

4. Qiao J, Pan L, Zhang B [et al.] Deferred Versus Immediate Stenting in Patients With ST-Segment Elevation Myocardial Infarction: A Systematic Review and MetaAnalysis. J. Am. Heart Assoc. 2017;6(3):e004838.

5. Patel VG, Michael TT, Mogabgab O [et al.]. Clinical, angiographic, and procedural predictors of periprocedural complications during chronic total occlusion percutaneous coronary intervention. J. Invasive Cardiol. 2014; 26(3):100105.

6. Ramana RK, Lewis BE. Percutaneous coronary intervention in patients with acute coronary syndrome: focus on bivalirudin. Vasc. Health Risk Manag. 2015;4(3):493-505. 


\title{
Recanalization of coronary arteries in patients with acute myocardial infarction
}

\author{
Aksonov E. V., Golovenko V. B., Gumenyuk B. M., Gaponenko A. E.
}

National M. M. Amosov Institute of Cardiovascular Surgery, National Academy of Medical Sciences of Ukraine (Kyiv)

The work is devoted to the study of early and delayed postoperative angiographic results in patients with acute myocardial infarction (AMI).

The survey included 626 patients with AMI without ST elevation, who underwent diagnostic and therapeutic interventional procedures for this pathology in the Angiographic Department of M.M. Amosov National Institute of Cardiovascular Surgery, National Academy of Medical Sciences of Ukraine.

The average age of patients was $66.96 \pm 1.81$ years; the average weight was $86.5 \pm 1.44 \mathrm{~kg}$. The area of the left ventricular (LV) myocardial infarction in the calculation of the QRS index was an average of $20.4 \pm 1.2 \% .438$ patients (69.97\%) were with II FC heart failure by T. Killip. Primary transcutaneous transluminal balloon angioplasty (PTTBA) was performed in 332 patients who were examined at the early stages of AMI, and 294 patients underwent surgical stenting of the infarctrelated artery (IRA) with single-stent implantation.

The research has showed that primary stenting was the most effective method for recanalization compared with emergency or delayed IRA stenting, manifested in a more significant decrease in the area of primary AMI compared with emergency stenting and delayed intervention.

In the group of patients who underwent IRA stenting, a correlation relationship was found between the development of residual coronary artery stenosis of more than $30 \%$ and baseline LV ejection fraction, baseline IRA blood flow and the ratio between the coronary artery diameter and the implantable stent diameter.

In a statistically equal number of cases of clinical success, hospital mortality was higher upon IRA stenting by $3 \%$ compared with PTTBA. However, the delayed results of the three-month follow-up showed the benefits of stenting over PTTBA in terms of lower rates of myocardial infarction reocclusion (by 11.3\%) and lower rates of delayed three-month lethality (by 6.7\%).

Key words: recanalization; acute myocardial infarction; coronary arteries. 